\title{
Resistance and Correlation of Pod Shattering and Selected Agronomic Traits in Soybeans
}

\author{
Richard Katembo Kataliko ${ }^{1,2}$, Paul M. Kimani ${ }^{2}$, James W. Muthomi ${ }^{2}$, Wothaya S. Wanderi ${ }^{3}$, Florence M. \\ Olubayo $^{2}$ \& Felister M. Nzuve ${ }^{2}$ \\ ${ }^{1}$ Faculty of agricultural sciences, Université Catholique du Graben (UCG), Butembo, Democratic Republic of \\ Congo \\ ${ }^{2}$ Department of Plant Science and Crop Protection, Faculty of Agriculture, University of Nairobi, Nairobi, Kenya \\ ${ }^{3}$ Kenya Agricultural Livestock and Research Organization, KALRO-Embu Research Center, Kenya \\ Correspondence: Richard Katembo Kataliko, Faculty of agricultural sciences, Université Catholique du Graben \\ (UCG), P.O. BOX 29 Butembo, Democratic Republic of Congo. Tel: 243-994-528-722. E-mail: \\ richardkataliko23@gmail.com
}

Received: November 22, $2018 \quad$ Accepted: December 7, 2018 Online Published: August 15, 2019

doi:10.5539/jps.v8n2p39

URL: https://doi.org/10.5539/jps.v8n2p39

\begin{abstract}
Pod shattering is a serious production constraint that causes 34 to $99 \%$ seed losses in soybean. Identification, development and utilization of varieties with resistance to pod shattering can reduce yield losses. However, there is limited information on genetic variability of this trait in local germplasm. Twenty soybean genotypes were evaluated at KALRO-Embu and KALRO-Mwea Research Centers, in Eastern and Central highlands of Kenya during the 2016 short and long rain seasons in an alpha lattice design arranged in a 4 x 5 pattern with three replicates. Data was collected on maturity, plant height, biomass, number of seeds per pod, pod shattering and grain yield and analyzed using Genstat software $\left(15^{\text {th }}\right.$ edition). Pearson's correlation estimates for pod shattering and agronomic traits was done using Statistix-8 statistical package. Results showed significant interactions between genotypes, sites and seasons for days to maturity, plant biomass and pod shattering. Seasonal and location effects were significant for all the traits measured except for plant height, grain yield and pod shattering. Genotype effects showed significances for all the traits. Results showed $17.87 \%$ of soybean pod shattering in Embu and $17.41 \%$ in Mwea; $16.58 \%$ during the long rains and $18.77 \%$ during the short rains. Based on their scores, ten genotypes were classified as resistant, seven as moderately resistant, one as moderately susceptible and two as highly susceptible. Genotypes SB-8 followed by Gazelle, SB-74, SB-4, Nyala and SB-20 were the most resistant. SB-93 and SB-25 were the most susceptible genotypes. Three varieties (931/5/34, 915/5/12 and SB-154) performed well with grain yields of up to $1800 \mathrm{~kg} \mathrm{ha}^{-1}$. The study found that pod shattering resistance was negatively correlated with number of seeds per pod $\left(\mathrm{r}=-0.13^{*}\right)$. Plant with few seeds per pod tended to have high resistance to pod shattering. The resistant genotypes can be utilized for production and in effective breeding programs.
\end{abstract}

Keywords: correlation, pod shattering, resistance and soybean

\section{Introduction}

With losses of up to $100 \%$ of seed, pod shattering has been recognized as the most important constraint to soybean production under tropic and sub-tropic regions (IITA, 1992; Adeyeye et al., 2014). Most of the varieties in the tropics are direct introductions from other regions where soybean has been grown for decades. However, resistant varieties introduced from other parts of the world often succumb to pod shattering in the tropics (Tukamuhabwa, 2000) probably due to differences in environment conditions, and genotype $\mathrm{x}$ environment interactions. Thus multi-season and multi-location evaluation of pod shattering is a pre-requisite to the identification of resistant genotypes which can fast tracked for production in the short-term and deployed for long-term use in breeding programs.

\section{Materials and Methods}

\subsection{Experimental Sites}

Field experiments were conducted at Embu and Mwea research stations from May 2016 to April 2017. Their 
descriptions are given in Table 1.

Table 1. Characteristics of the experimental sites

\begin{tabular}{lll}
\hline Characteristics & KALRO-Embu & KALRO-Mwea/Kirogo farm \\
\hline Latitude & $00^{\circ} 30^{\prime} \mathrm{S}$ & $00^{\circ} 37^{\prime} \mathrm{S}$ \\
Longitude & $37^{\circ} 42^{\prime} \mathrm{E}$ & $37^{\circ} 20^{\prime} \mathrm{E}$ \\
Elevation (Meters above sea level) & 1508 & 1159 \\
Annual rainfall $(\mathrm{mm})$ & $1200-1495$ & 850 \\
Annual maximum Temperature $\left({ }^{\circ} \mathrm{C}\right)$ & 25 & 28.6 \\
Annual minimum Temperatures $\left({ }^{\circ} \mathrm{C}\right)$ & 14.1 & 15.6 \\
Soil Type & Humic nitosol & Vertisols \\
Soil PH & 5.46 & 5.97 \\
\hline
\end{tabular}

Source: Wanderi, 2012; Njau, 2016

\subsection{Experimental Materials and Field Layout}

Twenty soybean genotypes were used in this study. Ten were SB varieties released in 2010 by IITA and the other ten were released in 2009 from KALRO-Njoro. Experiments were laid out in an alpha-lattice arranged in a 4 x 5 pattern with three replicates. A plot consisted of five rows of $2 \times 2 \mathrm{~m}$. Plants were spacing $15 \mathrm{~cm}$ within rows and $50 \mathrm{~cm}$ between rows. Diammonium phosphate $\left(18 \% \mathrm{~N}\right.$ and $\left.45 \% \mathrm{P}_{2} \mathrm{O}_{5}\right)$ was applied at $150 \mathrm{~kg} \mathrm{ha-}{ }^{1}$ before planting. Calcium ammonium nitrate $(26 \% \mathrm{~N})$ at $150 \mathrm{~kg} \mathrm{ha}^{-1}$ was used for top dressing. Plots were maintained weed free by manual cultivation. Furrow irrigation was done twice a week. Soil was flooded to field capacity at the time of irrigation. Plots were harvested at dry pod stage.

\subsection{Data Collection}

Data was collected on days to $75 \%$ maturity, plant height and biomass, number of seeds per pod, pod shattering and grain yield. Days to $75 \%$ maturity was recorded as the number of days from sowing to when approximately $75 \%$ of plants in a plot were physiologically mature. Plant height $(\mathrm{cm})$ was measured at flowering stage on the sample of six different plants as the distance from the ground to the top of the main stem. Plant biomass (g) was the average weight of a sample of six randomly selected plants at maturity within a plot. Seed per pod was determined by dividing the total number of seeds by the total number of pods from six plants. Pod shattering was determined by sun-drying a random sample of 50 fully mature pods for seven days of each variety in brown paper bags (IITA, 1992; Krisnawati and Adie, 2016). Shattered pods were then counted daily and expressed as percentage. Genotypes were finally categorized into five pod shattering classes based on their shattering reaction (Table 2). Grain yield was determined by weighing (g) threshed seeds from plants in the middle row, extrapolating to $\mathrm{kg} \mathrm{ha}^{-1}$ for each genotype (Wanderi, 2012).

Table 2. Asian vegetable research and development center scoring scale for pod shattering

\begin{tabular}{lll}
\hline Scale & Shattering percentage & Shattering score \\
\hline 1 & 0 & Very resistant (absolutely no shattered pod) (VR) \\
2 & $1-10$ & Resistant (R) \\
3 & $11-25$ & Moderately resistant (MR) \\
4 & $26-50$ & Moderately susceptible (MS) \\
5 & $>50$ & Very susceptible (HS) \\
\hline
\end{tabular}

AVRDC, 1979 ; Krisnawati and Adie, 2016

\subsection{Data Analysis}

All data was subjected to a combined analysis of variance using Genstat software (15 th edition) (Payne et al., 2009) with locations, seasons, replicates as random factors and genotypes as fixed factors. The percentage data on pod shattering was subjected to arcsine-square root transformation before analysis as recommended by Mohammed (2010). Fisher's Protected Least significant difference at 5\% probability levels was used for mean separation. Correlation between pod shattering and other agronomic traits was estimated using Statistix- 8 statistical package (Hall, 2015). 


\section{Results and Discussions}

\subsection{Days to $75 \%$ Maturity}

Significant interactions were found between genotypes and seasons. Significant variations were observed among locations, seasons and genotypes at $\mathrm{P}<0.001$ (Table 3). Climatic factors such as altitude, temperature and rainfall pattern were the probable causes of the observed differences. Indeed, the unreliable and erratic rainfall across sites was observed particularly in Mwea where a severe drought affected the maturation and negatively the biomass accumulation of late maturing varieties during the short rain season. This is consistent to Mugendi et al. (2011) and Vandamme et al. (2013) who made similar variations in western Kenya where maturation and biomass accumulation are affected by rainfall distribution. Except SB-19, most of SB varieties such as SB-145, SB-151, SB-154, SB-25, TGM 1420 and SB-20 were very late maturing (took more than 115 days), and had generally higher above ground biomass than local or commercial genotypes which varied from early to medium maturing varieties (took 80 to 115 days) (Table 4). Mean duration to maturity was 115 days. Genotypes took longer to mature in Embu than in Mwea. Days to maturity were longer during the short rain season compared with the long rain. In general, Black Hawk, Hill and SB-19 were early maturing genotypes and took less than 100 days to mature (Table 4 ).

Late maturing genotypes such as the SB lines had more biomass suggesting better use of the nutrients for biomass accumulation. Mahasi et al. (2010) reported that the late maturing genotypes were bred for biomass production unlike the earlier and medium maturing which were bred for grain production. These results are in agreement with Vanlauwe et al. (2003) who concluded that high biomass of soybeans is obtainable in late maturing than in the early maturing varieties.

\subsection{Plant Height}

Significant interactions were found between genotypes and locations; and genotypes and seasons. Significant differences were also found among genotypes, locations and seasons at $\mathrm{P}<0.001$ (Table 3). These findings agree with research results reported by Giller and Titonell (2013) that demonstrated that crop potential can be intensified by the interaction of factors such as genotype, environmental factors such as location and season. Significantly, shorter plants were found at Embu than Mwea. This is attributed to site variations. Wanderi (2012) reported that Embu and Mwea are different micro-ecological zones within eastern and central Kenya. The findings are in agreement with Janick (1972) who reported that increasing plant density accelerates the rate of plant growth hence the increased heights in closer spacing. The higher plant population at Mwea may have resulted in increased competition for essential growth factors like nutrients, sunlight and water. Average plant height during the long rain season was $40 \mathrm{~cm}$, which was associated with low observed plant density. Plants were generally taller $(55.6 \mathrm{~cm})$ during the short rain season, partly associated with a high plant density and high germination capacity. In addition, the amount of rainfall was higher and better distributed during the short rain season (Table 5). Plant density might have played additional role resulting in differences in plant height observed during the two cropping seasons. This is consistent with Amaglo et al. (2006) ; Augusto et al. (2014) who found that a good rainfall pattern and a closer spacing leads to higher increases in soybean plant height, while wider spacing shows relatively lower increases of plant height. Wycliffe (2015) on the other side, found that long rain soybean crop in western Kenya were generally taller compared to those grown during the short rains. Genotypes TGM-1420, SB-25 and SB-151 were the tallest lines across sites and seasons. On the other hand Black Hawk had the shortest plants. Generally, late maturing genotypes were taller than medium or early maturing genotypes. These findings are consistent to Mahasi et al (2010) and Ngalamu et al (2013) who found that late maturing varieties are taller than early maturing varieties due to their genetic composition and longer period to utilize the available resources optimally.

\subsection{Plant Biomass}

Significant interactions between genotypes, locations and seasons; genotypes and locations; genotypes and seasons were observed. Significant differences $(\mathrm{P}<0.001)$ were also detected. Plant biomass varied significantly among genotypes (Table 3). It ranged from 22 to $115 \mathrm{~g}$ with a mean of $73.12 \mathrm{~g}$. Except SB-19, SB genotypes with TGM-1420 recorded high biomasses compared to commercial varieties. Varieties SB-145 recorded the highest biomass. Black Hawk had the lowest (Table 6). These differences might be attributed to genetic diversity that characterizes soybean genotypes and also environmental effects. Plant biomass was higher at Embu compared to Mwea (Table 6). These variations were attributed to variations in rainfall, temperature and soil conditions of the test sites. Embu had an average annual rainfall of $943.7 \mathrm{~mm}$ and an average annual temperature of $23.1^{\circ} \mathrm{C}$ with a maximum of $26^{\circ} \mathrm{C}$ while Mwea received about $839.8 \mathrm{~mm}$ and an average temperature of $24.1^{\circ} \mathrm{C}$ with a maximum of $27.2^{\circ} \mathrm{C}$, during the experimental period (Tables 5). Soils at Embu humic nitosols 
while those at Mwea are vertisols (Wanderi, 2012).

The same trend was observed for the two seasons. Findings showed that biomass was $60.7 \%$ higher during the long rain season. During the short rains, there was a severe mid-season drought at Mwea which adversely affected plant growth and development especially during the reproductive phase as it coincided with pod setting stage. More reliable rainfall distribution was observed during long rain (Table 5). Findings were in agreement with Chianu et al. (2008) who reported that there is a tendency for many crops to fail during the short rain season but soybean generally survives due to its high drought tolerance but remarkable biomass losses are associated effects. The erratic and unreliable rainfall during the short rain season may have adversely affected vegetative growth, and hence the shoot biomass production. These findings agreed with Okoth et al. (2013) who indicated that mid-season drought has detrimental effects on soybean biomass accumulation.

Biomass of SB genotypes, late maturing genotypes, was three times more higher compared to commercial and local lines (94.6 g against $33.2 \mathrm{~g}$ ) (Table 6). This could be due to the longer period to maturity associated with SB genotypes, which allows plants to accumulate enough nutrients for high biomass production. Vanlauwe et al. (2003) also reported higher biomass accumulation in late maturing than in the early maturing soybean varieties.

\subsection{Number of Seeds per Pod}

Locations and seasons significantly affected the number of seeds per pod $(\mathrm{P}<0.001)$ (Table 3). At Embu, pods had an average of 2.24 seeds compared with 2.35 seeds per pod at Mwea. The mean number of seeds per pod varied from 2.20 for the long rain and 2.38 for the short rain (Table 6). These variations agree with Bodunde (1998) who reported that variations in temperature, rainfall and available nutrients are partly responsible for environmental differences. The variations might be attributed to environmental effects. Number of seeds per pod was also significantly affected by soybean genotypes. Line 915/5/12 and Black Hawk had the highest number of seeds per pod. On average pods of $915 / 5 / 12$ had 2.54 seeds, followed by 2.53 for Black Hawk. SB-20 with 2.03 seeds had the lowest number per pod. These differences in number of seeds formed were attributed to the genetic and also environmental factors that influence seed filling. The findings are in agreement with Nwofia et al. (2016) findings who reported that seeds per pod are associated with genetic make-up. These findings are also in agreement with the earlier report of RMRDC (2004) in which it was observed that the total output of soybean is dependent on genetic potential of the planting material.

\subsection{Pod Shattering}

This study revealed a wide range of resistance to pod shattering with significant differences among genotypes $(\mathrm{P}<0.001)$ (Table 3). Locations and seasons interacted significantly with genotypes $(\mathrm{P}<0.001)$ (Table 3$)$. The findings were in agreement with Agrawal et al. (2002) ; Tukamuhabwa et al. (2002) and Zhang and Boahen (2010) who started that the degree of soybean pod shattering depends upon the time of harvesting, the locations and the genotypes. This was attributed to environmental interactions with genetic potential of soybean materials. Tsuchiya (1987) ; Philbrook and Oplinger (1989) ; Agrawal et al. (2002) ; Tukamuhabwa et al. (2002) started before, that environmental factors such as drought stress during pod maturation has a significant impact on pod shattering. That might be the reason of an increase in pod shattering incidence observed particularly during the short rain season accompanied with dry weather conditions. Findings agreed more with Bhor et al. (2014) who reported that genotypic characteristics play a major role in the overall expression of pod shattering suggesting that differences could be attributed to variation in genetic information of soybean genotypes and seasonal weather conditions during growth and development.

Nevertheless, the reaction types used in this series of evaluations provided a good basis for classifying genotypes into resistant, moderately resistant, moderately susceptible and highly susceptible categories. SB varieties were the most resistant particularly SB-8 and SB-4. Varieties Gazelle and Nyala were the resistant among the commercial (Table 7). These findings agreed with Mahasi et al. (2012) whose findings during a study carried in western Kenya revealed that commercial varieties, Nyala and Gazelle, showed resistance and stability in pod shattering through three locations ; 'Bureti', 'Menengai' and 'Lare' when on the other side Shaahu et al. (2013), using most of SB varieties from IITA Ibadan in Nigeria, SB-8, SB-4, SB-20, SB-74, etc, found these materials to be resistant against pod shattering. They showed an average shattering percentage that varied between 1 to less than 15\% (Table 7). They remained stable throughout different agro-ecological zones. This stability may be due their genetic package or the genes that control that resistance as reported by Carpenter and Fehr (1986). SB varieties might have dominant resistance genes which control their ability of resistance to pod shattering. Susceptible varieties SB-90 and SB-25 might be controlled by six to twelve susceptible genes as reported by FIPs (2009). 


\subsection{Grain Yield}

There were significant differences $(\mathrm{P}<0.001)$ among genotypes (Table 3$)$. Grain yield ranged from $665.93 \mathrm{~kg} \mathrm{ha}^{-1}$ (cultivar Hill) to $1981.5 \mathrm{~kg} \mathrm{ha}^{-1}$ (line 931/5/34) with a mean of $1230.93 \mathrm{~kg} \mathrm{ha}^{-1}$. SB lines had higher grain yields compared to commercial varieties (1311.4 against $1171.9 \mathrm{~kg} \mathrm{ha}^{-1}$ ). Commercial varieties 931/5/34, 915/5/12 and SB-154 appeared well adapted (Table 7). The high yield of 931/5/34 was attributed to genetic potential for high stable productivity and efficient use of fertilizer applied. Alghamdi (2004); Vandamme et al. (2013) reported that yield of defined true varieties is more stable across diverse environments and growing periods. The high yield potential of variety 931/5/34 may also be due to contributions of its remarkable yield components such as 100-seed weight which is relatively high (more than $16 \mathrm{~g}$ ) as reported by Lynch (2011). Line 931/5/34 is a medium maturing genotype (112 days). Findings showed that most of medium-maturing genotypes had high grain yields compared to early maturing genotypes. These findings are consistent to observations during successive 15 years of experimentation carried on soybean variety trials in central Illinois region by Nafziger (2015). He reported that although yields of later-maturing varieties can be higher or lower than those of early-maturing ones depending on the year, mid-maturing varieties tend to yield slightly more than either early or late maturing. Lines 931/5/34 and 915/5/12 were mid-maturing varieties (between 95-115 days). Nafziger (2015) added that it is also clear that yields are much more closely tied to genetic potential than they are to maturity itself.

\subsection{Correlation between Pod Shattering and Selected Agronomic Traits}

Pod shattering resistance had slightly significant negative correlation $(\mathrm{r}=-0.13 *)$ with only number of seeds per pod at $\mathrm{P}<0.05$ (Table 8). That correlation showed that resistance to pod shattering increased towards reduced seed number within a pod. These findings are consistent to Morgan et al. (1998) and partly contradictory to those of Ghobnal and Denis (1979) ; Etebom (1987) ; Adeyeye (2014) who found no significant correlation of soybean pod shattering with number of seeds per pod and seed mass suggesting that these parameters were not useful as an index for pod shattering selection. The results are also partly contradictory to those of Child et al. (2003) whose findings illustrated that pod shattering is not linked to the number of seeds in pods. The negative correlation with pod shattering resistance suggested that high resistance to pod shattering is associated with low number of seeds per pod. This may be attributed to a good structure and consistency of pods that bear little seeds in number. Metcalfe et al. (1957) stated, however, that pod shattering resistance is closely related to its water content. Pod shattering was not significantly correlated with other selected traits.

Furthermore, significant grain yields resulted in late flowering genotypes with heavy plants. Late maturing genotypes resulted in late flowering lines with high plant height and larger seed size. High biomass was associated with late flowering materials, tall plants, larger seed size, high grain yield and in reduced number of seeds per pod at $\mathrm{P}<0.05$ (Table 8 ).

Table 3. Mean squares for study traits of soybean grown at Embu and Mwea Research Centers during the 2016 long and short rains

\begin{tabular}{|c|c|c|c|c|c|c|c|}
\hline Source & Df & $\begin{array}{l}\text { Days to } \\
75 \% \text { maturity }\end{array}$ & $\begin{array}{l}\text { Plant } \\
\text { Height }(\mathrm{cm})\end{array}$ & $\begin{array}{l}\text { Plant } \\
\text { Biomass (g) }\end{array}$ & $\begin{array}{l}\text { Seeds } \\
\text { pod }^{-1} \\
\end{array}$ & $\begin{array}{l}\text { Pod } \\
\text { shattering }(\%)\end{array}$ & $\begin{array}{l}\text { Grain } \\
\text { yield }\left(\mathrm{kg} \mathrm{ha}^{-1}\right)\end{array}$ \\
\hline Replicates & 2 & 163.28 & 324.29 & 812.1 & 0.00129 & 42.45 & 304836 \\
\hline Seasons (S) & 1 & $65488.58 *$ & $13262.03 *$ & $70022.4^{*}$ & $1.95662^{*}$ & $287.87^{\mathrm{ns}}$ & $268403^{\mathrm{ns}}$ \\
\hline Error $_{1}$ & 2 & 193.65 & 8.06 & 821.6 & 0.08798 & 183.26 & 436961 \\
\hline Locations (L) & 1 & $550.55^{*}$ & $11392.96^{\text {ns }}$ & $143597.1^{*}$ & $0.70742 *$ & $8.88^{\mathrm{ns}}$ & $493207^{\mathrm{ns}}$ \\
\hline $\mathrm{L} \times \mathrm{S}$ & 1 & $4519.68 *$ & $4351.21^{\mathrm{ns}}$ & $10104 *$ & $0.00057^{\mathrm{ns}}$ & $98.2^{\mathrm{ns}}$ & $18038^{\mathrm{ns}}$ \\
\hline Error $_{2}$ & 4 & 167.49 & 188.37 & 417.2 & 0.01698 & 143.88 & 401800 \\
\hline Genotypes (G) & 19 & $2605.86^{*}$ & $3827^{*}$ & $25824.5^{*}$ & $0.33189^{*}$ & $3809.92 *$ & $2038572 *$ \\
\hline $\mathrm{G} \times \mathrm{S}$ & 19 & $920.36^{*}$ & $451.55^{*}$ & $5136^{*}$ & $0.13921 *$ & $566.48 *$ & $76508^{\mathrm{ns}}$ \\
\hline Gx L & 19 & $85.88^{\text {ns }}$ & $496.27 *$ & $12953.9 *$ & $0.05423^{\mathrm{ns}}$ & $515.55^{*}$ & $63124^{\mathrm{ns}}$ \\
\hline G x S x L & 19 & $57.6^{\mathrm{ns}}$ & $169.51^{\mathrm{ns}}$ & $4318.1^{*}$ & $0.03161^{\mathrm{ns}}$ & $554.49^{*}$ & $22354^{\mathrm{ns}}$ \\
\hline Pooled error & 152 & 37.82 & 88.88 & 814.7 & 0.04413 & 49.07 & 75900 \\
\hline
\end{tabular}

*Indicates significant difference at $\mathrm{P}<0.001$ and, ns indicates no significant difference 
Table 4. Days to 75\% maturity and plant height of soybean at Embu and Mwea research centers during the 2016 long and short rain seasons

\begin{tabular}{|c|c|c|c|c|c|c|c|c|c|c|}
\hline \multirow{3}{*}{$\begin{array}{l}\text { Trait } \\
\text { Site } \\
\text { Genotype }\end{array}$} & \multicolumn{5}{|c|}{ Days to $75 \%$ maturity } & \multicolumn{5}{|c|}{ Plant height (cm) } \\
\hline & Embu & & Mwea & & Mean & Embu & & Mwea & & Mean \\
\hline & $\begin{array}{l}\text { Long } \\
\text { rain }\end{array}$ & $\begin{array}{l}\text { Short } \\
\text { rain }\end{array}$ & $\begin{array}{l}\text { Long } \\
\text { rain }\end{array}$ & $\begin{array}{l}\text { Short } \\
\text { rain }\end{array}$ & & $\begin{array}{l}\text { Long } \\
\text { rain }\end{array}$ & $\begin{array}{l}\text { Short } \\
\text { rain }\end{array}$ & $\begin{array}{l}\text { Long } \\
\text { rain }\end{array}$ & $\begin{array}{l}\text { Short } \\
\text { rain }\end{array}$ & \\
\hline $915 / 5 / 12$ & 93.7 & 125.0 & 88.7 & 122.7 & 107.5 & 29.4 & 35.0 & 26.8 & 36.4 & 31.9 \\
\hline $931 / 5 / 34$ & 97.0 & 124.7 & 86.0 & 138.3 & 111.5 & 35.8 & 33.6 & 24.3 & 33.4 & 31.8 \\
\hline Black Hawk & 91.0 & 96.7 & 82.0 & 101.7 & 92.8 & 19.4 & 24.2 & 20.4 & 34.2 & 24.5 \\
\hline EAI-3600 & 113.7 & 103.3 & 95.7 & 104.0 & 104.2 & 28.7 & 24.3 & 33.9 & 55.0 & 35.5 \\
\hline Gazelle & 96.3 & 113.7 & 90.7 & 124.7 & 106.3 & 31.4 & 35.1 & 28.2 & 38.4 & 33.3 \\
\hline Hill & 111.0 & 99.3 & 83.7 & 101.7 & 98.9 & 23.9 & 25.6 & 18.7 & 33.8 & 25.5 \\
\hline Nyala & 95.7 & 107.3 & 91.3 & 114.3 & 102.2 & 28.3 & 22.0 & 18.3 & 32.2 & 25.2 \\
\hline SB-145 & 129.3 & 162.7 & 106.3 & 167.0 & 141.3 & 34.7 & 53.1 & 45.5 & 86.9 & 55.0 \\
\hline SB-151 & 111.5 & 133.7 & 102.7 & 150.0 & 124.5 & 43.8 & 69.6 & 62.8 & 118.2 & 73.6 \\
\hline SB-154 & 124.0 & 160.7 & 97.3 & 161.3 & 135.8 & 38.9 & 43.9 & 46.8 & 106.8 & 59.1 \\
\hline SB-19 & 86.3 & 111.7 & 81.0 & 116.0 & 98.7 & 34.4 & 38.5 & 45.5 & 60.8 & 44.8 \\
\hline SB-20 & 113.3 & 175.7 & 99.7 & 176.3 & 141.2 & 49.3 & 55.5 & 43.0 & 85.4 & 58.3 \\
\hline SB-25 & 120.7 & 138.7 & 103.7 & 148.3 & 127.8 & 69.2 & 62.7 & 73.3 & 108.7 & 78.5 \\
\hline SB-37 & 109.3 & 132.0 & 99.0 & 146.7 & 121.8 & 31.7 & 46.2 & 30.6 & 61.3 & 42.4 \\
\hline SB-4 & 103.3 & 159.0 & 96.7 & 155.7 & 128.7 & 38.9 & 57.5 & 55.2 & 72.6 & 56.0 \\
\hline SB-74 & 102.3 & 139.3 & 96.0 & 142.0 & 119.9 & 33.9 & 58.8 & 71.1 & 86.3 & 62.5 \\
\hline SB-8 & 98.7 & 138.0 & 93.3 & 140.3 & 117.6 & 53.7 & 56.0 & 66.6 & 81.0 & 64.3 \\
\hline SB-90 & 106.7 & 115.0 & 92.0 & 112.0 & 106.4 & 37.8 & 30.8 & 35.3 & 44.9 & 37.2 \\
\hline SCS-1 & 94.3 & 126.3 & 87.0 & 133.3 & 110.2 & 47.8 & 36.9 & 44.9 & 45.0 & 43.7 \\
\hline TGM-1420 & 118.3 & 141.0 & 109.7 & 160.3 & 132.3 & 50.7 & 79.3 & 75.8 & 113.3 & 79.8 \\
\hline MEAN & 105.8 & 130.0 & 94.1 & 136.0 & 116.0 & 38.1 & 44.4 & 43.4 & 66.7 & 48.2 \\
\hline $\mathrm{LSD}_{0.05}$ & 1.7 & 17.8 & 2.6 & 9.3 & 5.3 & 10.2 & 18.8 & 9.8 & 20.4 & 7.7 \\
\hline C.V & 1.0 & 8.3 & 1.6 & 4.2 & 5.6 & 16.3 & 25.6 & 13.7 & 18.5 & 19.7 \\
\hline
\end{tabular}

LSD - least significant difference, $\mathrm{CV}$ - coefficient of variation

Table 5. Monthly means of rainfall and temperature at KALRO-Embu and KALRO-Mwea/Kirogo farm during the 2016 long and short rain seasons

\begin{tabular}{|c|c|c|c|c|c|c|c|c|c|}
\hline \multirow[b]{3}{*}{ Month } & \multicolumn{5}{|c|}{ Long rain } & \multicolumn{4}{|c|}{ Short rain } \\
\hline & \multicolumn{2}{|c|}{ KALRO-Embu } & \multicolumn{2}{|c|}{ KALRO-Mwea } & \multirow[b]{2}{*}{ Month } & \multicolumn{2}{|c|}{ KALRO-Embu } & \multicolumn{2}{|c|}{ KALRO-Mwea } \\
\hline & $\begin{array}{l}\text { Rain } \\
\text { (mm) }\end{array}$ & $\begin{array}{l}\text { Temp. } \\
\left({ }^{\circ} \mathrm{C}\right)\end{array}$ & $\begin{array}{l}\text { Rain } \\
(\mathbf{m m})\end{array}$ & $\begin{array}{l}\text { Temp. } \\
\left({ }^{\circ} \mathrm{C}\right)\end{array}$ & & $\begin{array}{l}\text { Rain } \\
(\mathbf{m m})\end{array}$ & $\begin{array}{l}\text { Temp } \\
\left({ }^{\circ} \mathrm{C}\right)\end{array}$ & $\begin{array}{l}\text { Rain } \\
\text { (mm) }\end{array}$ & $\begin{array}{l}\text { Temp } \\
\left({ }^{\circ} \mathrm{C}\right)\end{array}$ \\
\hline May 2016 & 96.8 & 22.9 & 100.7 & 23.7 & Nov 2016 & 138.2 & 21.7 & 102 & 22.6 \\
\hline June 2016 & 57 & 22 & 59.3 & 22.8 & Dec 2016 & 19.5 & 22.6 & 15.1 & 23.7 \\
\hline July 2016 & 49.6 & 19.5 & 51.6 & 20.3 & Jan 2017 & 39.2 & 24 & 27.3 & 25.1 \\
\hline Aug 2016 & 62.4 & 23 & 64.9 & 23.8 & Feb 2017 & 27.4 & 24.5 & 21.2 & 25.7 \\
\hline Sept 2016 & 67.4 & 24 & 70.1 & 24.8 & Mar 2017 & 87.8 & 26 & 68 & 27.2 \\
\hline Oct 2016 & 107 & 23 & 111.3 & 23.8 & Apr 2017 & 191.4 & 24 & 148.3 & 25.2 \\
\hline Total & 440.2 & - & 457.9 & - & Total & 503.5 & - & 381.9 & - \\
\hline Mean & 73.36 & 22.4 & 76.3 & 23.2 & Mean & 83.91 & 23.8 & 63.65 & 24.9 \\
\hline
\end{tabular}


Table 6. Plant biomass and number of seeds per pod of soybean genotypes at Embu and Mwea research centers during the 2016 long and short rain seasons

\begin{tabular}{|c|c|c|c|c|c|c|c|c|c|c|}
\hline \multirow{3}{*}{$\begin{array}{l}\text { Trait } \\
\text { Site } \\
\text { Genotype }\end{array}$} & \multicolumn{5}{|c|}{ Plant biomass (g) } & \multicolumn{5}{|c|}{ Number of seeds per pod } \\
\hline & \multicolumn{2}{|c|}{ Embu } & \multicolumn{2}{|l|}{ Mwea } & \multirow[t]{2}{*}{ Mean } & \multicolumn{2}{|c|}{ Embu } & \multicolumn{2}{|l|}{ Mwea } & \multirow[t]{2}{*}{ Mean } \\
\hline & $\begin{array}{l}\text { Long } \\
\text { rain }\end{array}$ & $\begin{array}{l}\text { Short } \\
\text { rain }\end{array}$ & $\begin{array}{l}\text { Long } \\
\text { rain }\end{array}$ & $\begin{array}{l}\text { Short } \\
\text { rain }\end{array}$ & & $\begin{array}{l}\text { Long } \\
\text { rain }\end{array}$ & $\begin{array}{l}\text { Short } \\
\text { rain }\end{array}$ & $\begin{array}{l}\text { Long } \\
\text { rain }\end{array}$ & $\begin{array}{l}\text { Short } \\
\text { rain }\end{array}$ & \\
\hline $915 / 5 / 12$ & 36.8 & 36.4 & 54.6 & 33.1 & 40.2 & 2.33 & 2.53 & 2.67 & 2.63 & 2.54 \\
\hline $931 / 5 / 34$ & 29.4 & 52.8 & 41.9 & 38.5 & 40.6 & 2.10 & 2.20 & 2.57 & 2.40 & 2.32 \\
\hline Black & 13.6 & 18.5 & 37.4 & 20.4 & 22.5 & 2.57 & 2.47 & 2.53 & 2.57 & 2.53 \\
\hline \multicolumn{11}{|l|}{ Hawk } \\
\hline EAI-3600 & 34.8 & 18.6 & 67.8 & 37.1 & 39.6 & 2.30 & 2.53 & 2.53 & 2.60 & 2.49 \\
\hline Gazelle & 41.0 & 13.8 & 69.9 & 21.7 & 36.6 & 2.30 & 2.53 & 2.57 & 2.57 & 2.49 \\
\hline Hill & 18.6 & 15.9 & 44.0 & 19.1 & 24.4 & 2.43 & 2.27 & 2.47 & 2.67 & 2.46 \\
\hline Nyala & 35.3 & 13.5 & 39.6 & 26.8 & 28.8 & 2.33 & 2.27 & 2.37 & 2.80 & 2.44 \\
\hline SB-145 & 53.6 & 56.3 & 517.2 & 210.1 & 209.3 & 2.20 & 2.2 & 2.17 & 2.33 & 2.23 \\
\hline SB-151 & 148.6 & 62.2 & 164.1 & 102.8 & 119.4 & 1.90 & 2.57 & 1.97 & 2.55 & 2.25 \\
\hline SB-154 & 106.1 & 58.2 & 196.2 & 99.7 & 115.0 & 1.70 & 2.40 & 1.80 & 2.45 & 2.09 \\
\hline SB-19 & 17.6 & 16.1 & 69.0 & 38.7 & 35.3 & 2.13 & 2.27 & 2.00 & 2.27 & 2.17 \\
\hline SB-20 & 116.4 & 50.3 & 113.9 & 135.2 & 103.9 & 2.00 & 2.09 & 2.03 & 2.00 & 2.03 \\
\hline SB-25 & 132.9 & 47.2 & 167.8 & 103.7 & 112.9 & 2.23 & 2.12 & 2.23 & 2.18 & 2.19 \\
\hline SB-37 & 83.3 & 29.4 & 121.1 & 56.6 & 72.6 & 1.90 & 2.18 & 2.00 & 2.28 & 2.09 \\
\hline SB-4 & 50.5 & 68.8 & 121.9 & 70.9 & 78.0 & 2.27 & 2.27 & 2.27 & 2.40 & 2.30 \\
\hline SB-74 & 28.2 & 53.5 & 111.9 & 134.9 & 82.1 & 2.17 & 2.37 & 2.23 & 2.52 & 2.32 \\
\hline SB-8 & 48.1 & 49.5 & 104.0 & 144.8 & 86.6 & 2.10 & 2.67 & 2.17 & 2.58 & 2.38 \\
\hline SB-90 & 65.3 & 22.4 & 130.4 & 18.9 & 59.3 & 1.80 & 2.00 & 2.30 & 2.40 & 2.13 \\
\hline SCS-1 & 33.3 & 22.1 & 77.7 & 36.5 & 42.4 & 1.83 & 2.33 & 1.90 & 2.17 & 2.06 \\
\hline TGM-1420 & 91.5 & 55.8 & 172.7 & 130.6 & 112.7 & 2.30 & 2.32 & 2.37 & 2.32 & 2.33 \\
\hline MEAN & 59.3 & 38.1 & 121.1 & 74.0 & 73.1 & 2.14 & 2.33 & 2.26 & 2.43 & 2.29 \\
\hline $\operatorname{LSD}_{0.05}$ & 53.8 & 25.3 & 57.6 & 45.3 & 46.3 & 0.43 & 0.30 & 0.37 & 0.25 & 0.17 \\
\hline C.V & 55.0 & 40.2 & 28.8 & 37.0 & 39.3 & 12.3 & 7.8 & 10.0 & 6.2 & 9.2 \\
\hline
\end{tabular}

LSD - least significant difference, CV - coefficient of variation

Table 7. Pod shattering and grain yield of soybeans at Embu and Mwea Research Centers during the 2016 long and short rain seasons

\begin{tabular}{|c|c|c|c|c|c|c|c|c|c|c|c|}
\hline \multirow{3}{*}{$\begin{array}{l}\text { Trait } \\
\text { Site } \\
\text { Season } \\
\text { Genotype } \\
\end{array}$} & \multicolumn{6}{|c|}{ Pod shattering \% } & \multicolumn{5}{|c|}{ Grain yield $\left(\mathrm{kg} \mathrm{ha}^{-1}\right)$} \\
\hline & \multicolumn{2}{|l|}{ Embu } & \multicolumn{2}{|l|}{ Mwea } & \multirow[t]{2}{*}{ Mean score } & \multirow{2}{*}{$\begin{array}{l}\text { Combined } \\
\text { reaction type }\end{array}$} & \multicolumn{2}{|l|}{ Embu } & \multicolumn{2}{|l|}{ Mwea } & \multirow[t]{2}{*}{ Mean } \\
\hline & Long rain & Short rain & Long rain & Short rain & & & Long rain & Short rain & Long rain & Short rain & \\
\hline $915 / 5 / 12$ & 6.7 & 2.7 & 0.0 & 52.7 & 3 & MR & 2011.8 & 1676.3 & 2121.8 & 1694.8 & 1876.2 \\
\hline $931 / 5 / 34$ & 56.7 & 79.5 & 51.7 & 0.7 & 4 & MS & 2201.1 & 2086.7 & 2125.6 & 1512.6 & 1981.5 \\
\hline Black Hawk & 14.6 & 3.3 & 13.0 & 21.3 & 3 & MR & 1079.3 & 1043.3 & 1023.0 & 1037.0 & 1045.6 \\
\hline EAI-3600 & 4.0 & 26.9 & 1.3 & 13.9 & 3 & MR & 972.4 & 927.8 & 989.6 & 1244.4 & 1033.6 \\
\hline Gazelle & 2.7 & 1.3 & 1.3 & 11.3 & 2 & $\mathbf{R}$ & 676.3 & 694.1 & 808.1 & 778.9 & 739.3 \\
\hline Hill & 20.2 & 0.7 & 18.5 & 49.0 & 3 & MR & 696.7 & 625.6 & 645.2 & 696.3 & 665.9 \\
\hline Nyala & 2.7 & 6.0 & 1.3 & 14.5 & 2 & $\mathbf{R}$ & 948.9 & 648.9 & 1229.0 & 1096.3 & 980.8 \\
\hline SB-145 & 16.3 & 4.7 & 16.3 & 6.7 & 2 & $\mathbf{R}$ & 1270.4 & 1220.2 & 1207.0 & 1324.2 & 1255.5 \\
\hline SB-151 & 17.9 & 2.7 & 17.9 & 4.7 & 2 & $\mathbf{R}$ & 1540.9 & 1582.2 & 1657.0 & 1580.5 & 1596.9 \\
\hline SB-154 & 14.6 & 13.9 & 14.6 & 12.6 & 3 & MR & 1724.7 & 1823.3 & 1805.9 & 1982.1 & 1834.0 \\
\hline SB-19 & 11.3 & 35.0 & 13.0 & 12.0 & 3 & MR & 1002.2 & 899.3 & 951.1 & 1022.2 & 985.4 \\
\hline SB-20 & 9.7 & 4.0 & 8.3 & 6.0 & 2 & $\mathbf{R}$ & 1571.1 & 1551.8 & 1719.8 & 1659.3 & 1625.5 \\
\hline SB-25 & 36.0 & 79.1 & 46.1 & 55.4 & 5 & HS & 808.7 & 690.4 & 854.9 & 761.5 & 778.8 \\
\hline SB-37 & 17.9 & 0.7 & 20.2 & 2.0 & 2 & $\mathbf{R}$ & 662.4 & 731.1 & 721.8 & 819.6 & 733.7 \\
\hline SB-4 & 6.7 & 4.7 & 5.7 & 6.0 & 2 & $\mathbf{R}$ & 1280.8 & 1231.8 & 1377.5 & 1473.2 & 1340.8 \\
\hline SB-74 & 9.7 & 0.0 & 9.7 & 2.7 & 2 & $\mathbf{R}$ & 1470.4 & 1370.4 & 1599.5 & 1738.4 & 1544.6 \\
\hline SB-8 & 8.3 & 0.7 & 0.0 & 2.0 & 2 & $\mathbf{R}$ & 146.00 & 1365.9 & 1539.3 & 1486.6 & 1462.9 \\
\hline SB-90 & 61.7 & 83.4 & 46.1 & 82.6 & 5 & HS & 1443.4 & 1102.2 & 1561.9 & 1037.0 & 1286.1 \\
\hline SCS-1 & 8.3 & 2.0 & 9.9 & 17.9 & 2 & $\mathbf{R}$ & 903.7 & 837.8 & 1188.1 & 1281.5 & 1052.8 \\
\hline TGM-1420 & 22.5 & 15.3 & 20.2 & 10.7 & 3 & MR & 802.9 & 761.5 & 828.5 & 804.1 & 799.2 \\
\hline
\end{tabular}




\begin{tabular}{|c|c|c|c|c|c|c|c|c|c|c|c|}
\hline Mean & 17.4 & 18.3 & 15.8 & 19.2 & - & - & 1227.8 & 1143.5 & 1301.1 & 1251.5 & 1231.0 \\
\hline LSD5\% & 10.5 & 6.8 & 14.2 & 13.3 & - & - & 319.9 & 573.3 & 266.1 & 572.5 & 240.2 \\
\hline $\mathrm{CV}$ & 36.6 & 22.4 & 54.7 & 41.8 & - & - & 15.8 & 30.3 & 12.4 & 27.7 & 24.2 \\
\hline
\end{tabular}

LSD - least significant difference, $\mathrm{CV}$ - coefficient of variation

Table 8. Correlation coefficients between pod shattering and selected agronomic traits of soybean at Embu and Mwea research centers during the 2016 long and short rain seasons

\begin{tabular}{lcllll}
\hline & DTM & PH & Biomass & Seeds per pod & Yield \\
\hline PH & $0.5899^{* *}$ & & & & \\
Biomass & 0.1041 & $0.3803^{* *}$ & & & \\
Seeds per pod & 0.0179 & -0.0351 & $-0.2398^{* *}$ & & \\
Yield & 0.0968 & 0.1151 & $0.1567^{*}$ & -0.0506 & \\
Shatter \% & -0.0833 & -0.0538 & -0.0297 & $-0.1304^{*}$ & 0.0025 \\
\hline
\end{tabular}

*Indicates significant at $\mathrm{P} \leq 0.05$ and $* *$ indicates significant at $\mathrm{P} \leq 0.01 ; \mathrm{PH}=$ plant height, $\mathrm{DTM}=$ days to $75 \%$ maturity

\section{Conclusion and Recommendation}

The objective of this study was to determine if there is genotypic variation for resistance to pod shattering and other agronomic traits among local and introduced soybean genotypes and also to determine the correlation between resistance to pod shattering and selected agronomic traits of soybean. Results indicated considerable variation for pod shattering and selected agronomic traits. Resistant varieties included Gazelle, Nyala, SCS-1, SB-145, SB-151, SB-20, SB-37, SB-4, SB-74 and SB-8. Most of these genotypes were SB lines from IITA. The first three genotypes were commercial varieties. Most of SB varieties produced high seed yield and biomass. Resistance to pod shattering is found to be negatively correlated with the number of seeds per pod. This implies that resistance to pod shattering is associated with few seeds per pod. The resistant lines provide potentially useful sources of resistance that may be introgressed into susceptible commercial varieties or breeding lines. Thus further studies are needed to characterize the resistance genes present in the most resistant genotypes to facilitate an effective and efficient soybean breeding program.

\section{Acknowledgments}

This publication was made possible through support provided by Alliance for a Green Revolution in Africa (AGRA) Grant No. 2015 PASS 011. The opinions expressed herein are those of the authors and do not necessarily reflect the views of AGRA.

\section{References}

Adeyeye, A. S., Togun, A. O., Akanbi, W. B., Adepoju, I. O., \& Ibirinde, O. (2014). Pod shattering of different soybean varieties, Glycine max (L) Merrill, as affected by some growth and yield parameters. Inter. J. Agric. Policy and Res. 2(1), 10-015. Retrieved from http://journalissues.org/wp-content/u...

Agrawal, A. P., Basarkar, P. W., Salimath, P. M., \& Patil, S. A. (2002). Role of cell wall-degrading enzymes in pod shattering process of soybean. Current Science, 82(1), 58-60.

Alghamdi, S. S. (2004). Effects of Soybean Planting Dates and Various Cultivars of Differing Maturity Groups on the Incidence on Severity of Sudden Death Syndrome. M.Sc. thesis, Southern Illinois University, Carbondale, USA.

Amaglo, N. K., Timpo, G. M., Ellis, W. O., Bennett. R. N., \& Foidl, N. (2006). Effect of spacing and harvest frequency on the growth and leaf yield of moringa (Moringa oleifera), a leafy vegetable crop. Ghana Journal of Horticulture, 17(8), 33-40. Retrieved from http://hdl.handle.net/123456789/9664.

Asian Vegetable Research and Development Center (AVRDC) (1979). The World vegetable Center, Shanhua, Taiwan. AVRDC publication, 778(14), 1-92. Retrieved from https://avrdc.org/

Augusto, N. S., Garrido, D. P., Junior, A. Z., Fernandes, L. G., Schmitz, T., Marques, R., Trevisan, A., \& Rocha, M. (2014). Effect of plant spacing on growth, development and yield of cassava in a subtropical environment. Bragantia, 73(4), 407-415. https://doi.org/10.1590/1678-4499.0159

Bhor, T. J., Chimote, V. P., \& Deshmukh, M. P. (2014). Inheritance of pod shattering in soybean [Glycine max (L.) Merr.]. Electric J. of Plant Breed, 5(4), 671-676. Retrieved from http://ejplantbreeding.com/index.php?

Bodunde, J. G. (1998). Yield and Yield-Related Characters of Tomatoes Plants as Indices of Irrigation Efficiency 
in Conventional Ridge Side and Basin Plant-Placement Under High Environmental Temperature. $16^{\text {th }}$ hortson Conference (1), 7-10 ${ }^{\text {th }}$ September 1998, Abeokuta.

Carpenter, J. A., \& Fehr, W. R. (1986). Genetic variability for desirable agronomic traits in population containing Glycine soja germplasm. Crop Sci., 26, 681-686. https://doi.org/10.2135/cropsci1986.0011183X002600040008x

Philbrook, B., \& Oplinger, E. S. (1989). Soybean field losses as influenced by harvest delays. Agronomy Journal, 81(9), 251-258. https://doi.org/10.2134/agronj1989.00021962008100020023x

Lynch, J. P. (2011). Roots phenes for enhanced soil exploration and phosphorus acquisition. Tools for future crops. Plant physiology, 156(3), 1041-1049. https://doi.org/10.1104/pp.111.175414

Chianu, J. N., Vanlauwe, B., Mahasi, J. M., Katungi, E., Akech, C., Mairura, F. S., Chianu, J. N., \& Sanginga, N. (2008). Soybean situation and outlook analysis: the case of Kenya, Nairobi, Kenya.

Farm Input Promotions Africa Ltd (FIPs) (2009). Specification for the advanced Encryption standard. Kenya. Retrieved from http://csrc.nist.gov/publications/fips/fips197/fips-197.pdf

Giller, K. E., \& Titonell, P. A. (2013). When yield gaps are poverty traps: The paradigm of ecological intensification in African smallholder agriculture. Field Crops Research, 143(5), 76-90. https://doi.org/10.1016/j.fcr.2012.10.007

International Institute of Tropical Agriculture (IITA) (1992). Archival Report. Grain Legume Improvement program, Ibadan, Nigeria.

Janick, J. (1972). Horticultural Science, $2^{\text {nd }}$ Edition. Freeman and Company, San Francisco, USA.

Krisnawati, A., \& Adie, M. M. (2016). Pod shattering resistance in different soybean genotypes. Proceedings of ILETRI National Seminar. ILETRI, IAARD, Malang. https://doi.org/10.13057/biodiv/d180111

Mahasi, J. M., Vanlauwe, B., Mursoy, R. C., Mbehero, P., \& Mukalama, J (2012). Increasing productivity of soybean in western Kenya through evaluation and farmer participatory variety selection. KALRO-Njoro, CIAT-Nairobi, Kenya.

Mahasi, J. M., Vanaluwe, B., Mursoy, R. C., Mbehero, P., \& Mukalama, J. (2010). Increasing Productivity of Soybean in Western Kenya through Evaluation and Farmer Participatory Variety Selection. KALROBiennial Conference, Nairobi Kenya.

Mohammed, H. (2010). Genetic analysis of resistance to pod shattering in soybean (Glycine max.), Msc thesis. Kwame Nkrumah University, Kumasi. Retrieved from http://ir.knust.edu.gh/handle/123456789/153

Mugendi, D. N., Waswa, B. S., Mucheru-Muna, M. W., Kimetu, J. M., \& Palm, C. (2011). Comparative analyses of the current and potential role of legumes in integrated soil fertility management in east Africa. Fighting poverty in Sub-Sahara Africa: The Multiple role of legumes in integrated soil fertility management, Netherlands, 151-173. https://doi.org/10.1007/978-94-007-1536-3_7

Nafziger, E. (2015). Soybean plant date and varietal maturity, news release. University of Illinois, USA.

Ngalamu, T., Muhammmad, A., \& Silvestro, M. (2013). Soybean genotype and environmental interaction effect on yield and other related traits. American Journal of Experimental Agriculture, 3(4), 977-987. https://doi.org/10.9734/AJEA/2013/5069

Njau, S. N. (2016). Selection for yield potential, disease resistance and canning quality in runner and snap bean lines and populations. MSc. thesis, University of Nairobi, Nairobi, Kenya.

Njoroge, J. N., Owouche, J. O., \& Oyoo, M. E. (2015). Evaluation of soybean [Glycine max (L.) Merr.] genotypes for agronomic and quality traits in Kenya. African Jour. of Agric. Res., 10(12), 1474-1479. https://doi.org/10.5897/AJAR2014.9168

Nwofia, G. E., Edugbo, R. E., \& Mbah, E. U. (2016). Interaction of Genotype x Sowing Date on Yield and Associated Traits of Soybean [Glycine $\max$ (L.) Merrill] over Two Cropping Seasons in a Humid Agro-ecological Zone of South-Eastern Nigeria. The Jour. of Agric. Sci., 11(3), 164-177. https://doi.org/10.4038/jas.v11i3.8170

Okoth, R. O., Odunga, P. O., \& Oduke, C. O. (2013). Role of Community Capacity Building in Ensuring Sustainability of Food Security Project: A Case of the Millennium Villages Project in Bar Sauri, GemKenya. Greener J. of Agric. Sciences, 3(10), 678-686. https://doi.org/10.15580/GJAS.2013.3.072413749

Payne, R. W., Murray, D. A., Harding, S. A., Baird, D. B., \& Soutar, D. M. (2009). Genstat for windows $\left(15^{\text {th }}\right.$ Ed.) 
Introduction. VSN International, Hemel Hempstead, UK.

Raw Material Research and Development Council (RMRDC) (2004). Report on survey of selected agricultural raw materials in Nigeria. Ibadan, Nigeria.

Shaahu, A., Bello, L., \& Vange, T. (2013). Correlation, path coefficient and principal component analysis of seed yield in soybean genotypes. Federal University of Agriculture, PMB 2373 Makurdi, Benue State, Nigeria.

Tsuchiya, T. (1987). Physiological and genetic analysis of pod shattering in soybeans. Japan Agric Res Quart, 21(3), 166-175. https://doi.org/10.1111/j.14321033.1987.tb11187.x

Tukamuhabwa, P. (2000). Genetics of resistance to pod shattering in soybean. $\mathrm{PhD}$ thesis. Makerere University, Kampala. Uganda.

Tukamuhabwa, P., Dashiell, K. E., Rubaihayo, P., \& Nabasirye, M. (2002). Determination of field yield loss and effect of environment on pod shattering in soybean. African Crop Sci. J., 10, 203-209. Retrieved from https://hdl.handle.net/10568/92754

Vandamme, E., Renkens, M., Pypers, P., Smolders, E., Vanlauwe, B., \& Merckx, R. (2013). Root hairs explain P uptake efficiency of soybean genotypes grown in a P-deficient Ferralsol. Plant and Soil, 369(2), 269-282. https://dx.doi.org/10.1007/s11104-012-1571-2

Vanlauwe, B., Mukalama, J., Abaidoo, R., \& Sanginga, N. (2003). Soybean varieties, developed in West Africa, retain their promiscuity and dual- purpose nature under Western Kenyan conditions. African Crop Science Conference Proceedings 6-8 Aug., Kenya.

Wanderi, S. W. (2012). Genetic analyses for resistance to soybean rust (Phakopsora pachyrhizi) and yield stability among soybean genotypes in Kenya. Ph.D. thesis, University of KwaZulu-Natal, South-Africa.

Wycliffe, W. W. (2015). Evaluation of yield potential and management practices affecting soybean production in Western Kenya. MSc. thesis, University of Eldoret, Kenya.

Zhang, L., \& Boahen, S. (2010). Evaluation of critical shattering time of early maturity soybeans under early soybean production system. Agric Biol. J. North Amer., 1(4), 440-447.

https://doi.org/10.5251/abjna.2010.1.4.440.447

\section{Copyrights}

Copyright for this article is retained by the author(s), with first publication rights granted to the journal.

This is an open-access article distributed under the terms and conditions of the Creative Commons Attribution license (http://creativecommons.org/licenses/by/4.0/). 